\title{
PENGARUH KELOMPOK REFERENSI, MOTIF EKONOMI DAN PENDIDIKAN KEWIRAUSAHAAN DI SEKOLAH TERHADAP INTENSI BERWIRAUSAHA SISWA SMK DI KOTA MALANG
}

\author{
Finisica Dwijayati Patrikha, Universitas Negeri Surabaya \\ vivien_patrikha@yahoo.com
}

\begin{abstract}
ABSTRAK
Penelitian ini ditujukan untuk mengetahui intensi berwirausaha siswa SMK di Kota malang yang dipengaruhi oleh kelompok referensi, motif ekonomi dan pendidikan kewirausahaan di sekolah. Responden penelitian berjumlah 261 siswa. Pengumpulan data dilakukan dengan pendekatan mix-method, dengan data kuantitatif dengan menggunakan analisis regresi yang dilengkapi dengan data kualitatif dengan wawancara mendalam. Hasil penelitian ini menunjukkan bahwa kelompok referensi dan pendidikan kewirausahaan di sekolah berpengaruh positif terhadap intensi berwirausaha siswa. Variabel motif ekonomi memiliki pengaruh yang kuat terhadap intensi berwirausaha siswa, motif untuk memenuhi kebutuhan, motif untuk memperoleh keuntungan, motif untuk memperoleh penghargaan, motif untuk memperoleh kekuasaan, dan motif sosial serta motif untuk memberikan yang lebih baik kepada keluarga menjadi alasan yang mendasar bagi siswa untuk memilih kewirausahaan sebagai pilihan karir mereka. Namun siswa masih kesulitan mengidentifikasikan langkah-langkah yang harus ditempuh untuk benar-benar memulai suatu usaha.

Kata kunci: kelompok referensi, motif ekonomi, pendidikan kewirausahaan di sekolah, intensi berwirausaha
\end{abstract}

\section{ABSTRACT}

This study aimed to determine the intentions for entrepreneurship by the vocational school students in the Malang city which are affected by the reference group, economic motives and entrepreneurship education in schools. Respondents are 261 students. Data were collected by mixed-method approach, which means quantitative data by regression analysis incorporating with qualitative data by indepth interviews. These results indicate that the reference group and entrepreneurship education positively affects students' entrepreneurial intentions. Variable economic motives have a strong influence on the intentions of entrepreneurship, the motive to fullfil their needs, to earn profit, to get the award, to gain power, and social motives, and motive to provide better condition for the family becomes the basic reason for students to choose entrepreneur as their career choice. However, students are still difficult to identify the steps that must be taken to start a business.

Keywords: reference group, economic motives, entrepreneurship education in schools, entrepreneurship intentions 


\section{PENDAHULUAN}

Sekolah Menengah Kejuruan dalam bidang ekonomi atau yang dahulu lebih dikenal dengan SMEA merupakan sekolah dengan dasar pendidikan ekonomi, yang bertujuan untuk menghasilkan sumber daya manusia berkualitas yang siap kerja di bidang ekonomi. SMK dalam bidang ekonomi memiliki berbagai jurusan atau bidang pembelajaran seperti kelas Bisnis dan Manajemen, Administrasi Perkantoran, Akuntansi dan Tata Niaga/ Pemasaran. Mata diklat kewirausahaan merupakan mata diklat yang diberikan secara umum di SMK sehingga semua jurusan memperoleh mata diklat kewirausahaan. Mata diklat kewirausahaan ini memiliki tujuan agar siswa: (1) dapat mengaktualisasikan diri dalam perilaku wirausaha; (2) dapat merencanakan pengelolaan usaha kecil; dan (3) dapat mengelola usaha kecil.

Lulusan SMK diharapkan menjadi lulusan yang siap bekerja dan dengan bekal keterampilan yang diperoleh dari sekolah diharapkan lulusan SMK tidak hanya menjadi pencari kerja melainkan dapat juga menjadi wirausaha. Namun kenyataannya siswa yang lebih memilih sebagai pencari kerja dibandingkan menjadi wirausaha. Hal ini dikarenakan adanya instansi atau perusahaan yang mencari siswa SMK (SMEA) berprestasi untuk dipekerjakan, bahkan sebelum siswa tersebut dinyatakan lulus dan memperoleh ijazah (Kompas, 2009).

Menurut teori perkembangan karir oleh Ginzberg (dalam Rahma, 2010), perkembangan seorang individu dalam menentukan pilihan pekerjaan dan karirnya melalui proses yang berlangsung dalam waktu yang relatif panjang dan melalui fase-fase perkembangan mengikuti perkembangan individu itu sendiri. Fase fantasi mencakup usia kira-kira sepuluh atau dua belas tahun, fase tentatif usia 11 sampai 18 tahun dan fase realistis yaitu masa anak mulai bekerja. Sesuai dengan teori perkembangan dan pemilihan karir yang dikemukakan oleh Ginzberg tersebut, maka dalam perkembangannya pilihan karir anak dipengaruhi oleh keluarga dan sekolahnya. Untuk itu merupakan tanggung jawab sekolah dan keluarga untuk meningkatkan intensi berwirausaha anak.

Capara et.al (2003) dalam penelitiannya mengemukakan bahwa orang tua yang memiliki keyakinan yang tinggi dalam mengawasi, mendukung, melindungi, mengarahkan, membesarkan hti, dan menyediakan waktu bagi anak-anaknya, memberikan hukuman apabila diperlukan sehingga tidak terjadi konflik, dapat membantu perkembangan aspirasi dan kemampuan anak, dengan demikian dapat meningkatkan hubungan sosial anak, kestabilan emosi, peningkatan prestasi dan pemilihan kerja atau karir yang hendak ditekuninya.

Pemilihan karir atau pekerjaan yang ditekuni oleh seseorang dalam perkembangannya melalui proses yang berlangsung dalam waktu yang relatif panjang dan melalui fase-fase perkembangan individu dari masa anak-anak sampai dewasa. Hal ini berarti pemilihan karir seseorang tidak dapat dilepaskan dari pengaruh kelompok referensinya dalam hal ini lingkungan keluarga dan teman sebaya. Dijelaskan pula oleh Chen dan Lai (2010) bahwa kegagalan dan keberhasilan keluarga dalam usaha memenuhi kebutuhannya akan mempengaruhi minat dan pilihan anak untuk memenuhi kebutuhannya sendiri di masa yang akan datang. Lingkungan keluarga yaitu dimana seseorang mendapatkan pendidikan pertamanya, teman sebaya dimana seseorang mengembangkan pergaulannya, pendidikan di sekolah dimana seseorang mendapatkan pendidikan lebih lanjut. 
Berdasarkan teori dan pengertian diatas mengarahkan peneliti untuk merumuskan hipotesis pertama yaitu:

$\mathrm{H}_{1}$ Kelompok referensi berpengaruh terhadap intensi berwirausaha siswa

Motif berasal dari kata latin yaitu motus yang berarti penggerak atau pendorong. Motif ekonomi berarti penggerak atau pendorong seseorang untuk melakukan kegiatan ekonomi, dorongan ini tidak terlepas dari adanya keinginan yang melatar belakangi seseorang untuk memenuhi kebutuhan ekonominya. Pada prakteknya motif ekonomi berdasarkan pada motif untuk memenuhi kebutuhan, motif untuk memperoleh keuntungan, motif untuk memperoleh penghargaan, motif untuk memperoleh kekuasaan, dan motif sosial (Dow, 2005).

Teori lain yang melandasi faktor motif ekonomi adalah teori tindakan beralasan ( Reasoned action theory) yang dikemukakan oleh Fishbein dan Ajzen seperti yang dikutip Jogiyanto (2007) tentang perilaku individu dalam menggunakan atau memilih suatu hal jika mereka merasakan atau meyakini bahwa hal tersebut akan membawa manfaat bagi individu tersebut. Individu akan memilih suatu produk dengan harapan produk tersebut dapat memberikan manfaat baginya dikemudian hari. Ajzen sendiri didukung oleh model perilaku dari Bandura (1991) yang dikembangkan Compeau seperti yang dikutip dalam Jogiyanto (2007) mengemukakan tentang ekspektasi hasil-hasil (outcomes expectation) yang mempengaruhi perilaku individu dalam memilih dan menggunakan, dimana individu akan berprilaku atau melakukan perilaku-perilaku apabila hasil-hasil yang mereka ekspektasikan menguntungkan dan bermanfaat bagi mereka.

Keputusan seseorang untuk memilih karir sebagai wirausaha dapat juga dipengaruhi oleh kelompok referensinya. Kelompok referensi diartikan sebagai suatu kelompok yang keanggotaanya berdasarkan kelompok sosial dimana individu tersebut berada. Kelompok referensi disini adalah keluarga dan teman sebaya. Kelompok referensi memiliki pengaruh yang potensial dalam membentuk sikap dan perilaku seseorang (Rani, 2014). Kelompok referensi dapat memberikan suatu keyakinan terhadap seseorang, baik melalui pengalaman, maupun sesuatu yang dipelajari. Peran kelompok referensi dapat dibagi menjadi dua hal dalam keputusan seseorang yaitu sebagai initiator atau pemberi ide dan influencer yang mempengaruhi untuk melakukan sesuatu sesuai dengan idealisme kelompok (Bristol \& Mangleburg, 2005). Faktor rekomendasi teman merupakan juga salah satu faktor kelompok anutan yang mempengaruhi perilaku konsumen dalam memilih lembaga pendidikan. Peran teman dalam menstimulus keputusan mahasiswa untuk memilih dan melakukan suatu tindakan sangatlah besar.

Kewirausahaan menjadi topik yang menarik bagi pelaku akademik, pelajar, dan para pembuat keputusan, serta pelaku bisnis. Meskipun banyak penelitian tentang kewirausahaan namun belum ada kesepakatan untuk mendefinisikan kewirausahaan itu sendiri (Kobia \& Sikalieh, 2010), dan tidak konsistensi dalam mendefinisikan kewirausahaan (Humbert \& Drew, 2010). Wirausaha menurut Soemanto (1999) adalah seseorang yang memiliki potensi untuk berprestasi, mampu menolong diri sendiri dan tidak suka bergantung pada orang lain. Suryana (2003) memberikan batasan bahwa ilmu kewirausahaan adalah suatu disiplin ilmu yang mempelajari tentang nilai, kemampuan dan perilaku seseorang dalam menghadapi tantangan hidup untuk memperoleh peluang dengan berbagai resiko yang mungkin dihadapinya. 
Sampai saat ini belum ada batasan baku dari para pakar untuk mendefinisikan kewirausahaan, namun semua definisi dan batasan kewirausahaan mengarah pada sifat atau watak individu yang mempunyai ciri-ciri berkemauan keras serta yakin dengan kemampuannya dalam mewujudkan gagasan inovatif ke dalam dunia usaha dan dapat mengembangkannya dan tangguh pada semua aspek pekerjaan yang dilakukannya. Dalam penelitian ini pengertian kewirausahaan diadopsi dari definisi yang dikemukakan oleh Yalcin dan Kapu (2008) yaitu kewirausahaan adalah " $a$ process with different important dimensions, including entrepreneurial motives, problems, and opportunities". Peran dari pendidikan dan pelatihan kewirausahaan dalam mengidentifikasi dan memelihara potensi kewirausahaan diantara orang muda menjadi nyata bagi para siswa, pembuat peraturan, dan para pendidik. Didukung oleh Instruksi Presiden RI Nomor 6 tahun 2009 tentang Pengembangan Ekonomi Kreatif, yang sasarannya antara lain adalah insan kreatif dengan pola pikir dan moodset kreatif, serta industri yang unggul di pasar dalam dan luar negeri, dengan peran dominan wirausahawan lokal.

Menurut Fatoki (2010) mengemukakan bahwa ada lima motif yang mempengaruhi intensi lulusan sekolah menengah untuk menjadi wirausaha antara lain pekerjaan, otonomi, kreatifitas, alasan ekonomi dan keuangan. Carraher et al. (2010) berargumen bahwa keinginan untuk mencapai sesuatu merupakan motif yang kuat bagi individu untuk menjadi wirausaha. Individu termotivasi untuk menjadi wirausaha ketika ia termotivasi untuk mencapai prestasi, otonomi, keinginan untuk menghindari frustasi dalam mencari kerja, dan keinginan untuk mengumpulkan uang. Singh et al (2011) menemukan bahwa motif pendidikan dan keuangan keluarga adalah alasan yang signifikan dalam mempengaruhi keputusan para wanita di Nigeria untuk berwirausaha, keinginan untuk memberikan kehidupan yang lebih baik kepada keluarga sangat mempengaruhi motif berwirausaha para wanita di Nigeria. Berdasarkan pengertian diatas mengarahkan peneliti untuk merumuskan hipotesis kedua yaitu:

$\mathrm{H}_{2}$ Motif ekonomi berpengaruh terhadap intensi berwirausaha siswa

Kota Malang merupakan kota di Jawa Timur yang menjadi daerah tujuan wisata baik domestik maupun internasional. Di Kota Malang tersedia berbagai tempat bagi para turis untuk berwisata, dari agrowisata, taman bermain hingga kuliner. Pertumbuhan ekonomi kota Malang diantara 7 sampai 8 persen pertahunnya dan jumlah penduduk yang bekerja sendiri menurut badan pusat statistik kota malang (BPS) selalu meningkat setiap tahunnya. Berdasarkan wawancara yang dilakukan sebelumnya kepada wirausahawan untuk mengetahui alasan pemilihan karir diketahui bahwa motif ekonomi mempengaruhi keputusan tersebut. Melihat kondisi ekonomi dan pariwisata Kota Malang yang meningkat setiap tahunnya sehingga mereka memutuskan untuk berwirausaha. Sehingga variabel motif ekonomi menjadi alasan dalam memilih karir. Untuk itu peneliti tertarik melakukan penelitian dengan judul pengaruh kelompok referensi, motif ekonomi dan pendidikan kewirausahaan di sekolah terhadap intensi berwirausaha siswa SMK di Kota Malang.

Rata-rata pertumbuhan wirausaha berbeda disetiap daerah, daerah yang menjadi tujuan wisata memiliki rata-rata yang lebih tinggi dibandingkan dengan daerah yang kurang menjadi referensi wisata (Acs and Amorós, 2008). Pemerintah daerah seharusnya mengembangkan strategi untuk memotivasi wirausahawan karena wirausaha merupakan pemicu perkembangan ekonomi, 
ketenagakerjaan, persaingan dan inovasi (Thurik \& Wennekers, 2004; Grilo and Irigoyen, 2006; Acs et al, 2008). Dengan adanya dukungan pemerintah diharapkan lebih banyak orang yang termotivasi untuk memilih karir menjadi wirausaha.

Pendidikan kewirausahaan yang diberikan di sekolah adalah pendidikan yang menerapkan prinsip-prinsip dan metodologi ke arah pembentukan kecakapan hidup (life skills) pada seperta didiknya melalui kurikulum yang terintegrasi yang dikembangkan oleh sekolah. Sesuai dengan penelitian Birdthisle, et.al (2007) pendidikan di sekolah kejuruan didasarkan pada life skills. Life skills merupakan kemampuan yang diperlukan sepanjang hayat, sehingga siswa yang mendapatkan pendidikan yang didasarkan pada life skills akan memiliki kemampuan untuk berfikir yang kompleks atau memiliki pemikiran yang jauh kedepan, memiliki kemampuan berkomunikasi yang efektif, mampu bekerjasama, serta cakap untuk masuk dunia kerja. Diharapkan melalui pendidikan kewirausahaan di sekolah kejuruan, siswa tertarik untuk menjadi seorang wirausaha dibandingkan menjadi pencari kerja, sesuai dengan salah satu tujuan pendidikan kewirausahaan di sekolah yaitu meningkatkan jumlah wirausaha yang berkualitas.

Kotter (1997) menyatakan bahwa wirausahawan yang ada di Amerika bukan merupakan siswa yang pintar disekolah, bahkan merupakan siswa yang kurang berprestasi disekolah. Untuk itu pendidikan kewirausahaan di sekolah lebih kepada penyampaian materi dan bagaimana proses pembelajarannya bukan kepada hasil yang dicapai. Lebih lanjut Kotter menjelaskan bahwa minat berwirausaha kurang dipengaruhi oleh pendidikan yang diterima di sekolah. Masalah ini berkaitan dengan pelaksanaan pendidikan kewirausahaan di sekolah yang lebih kepada membekali siswa hanya sebatas pengetahuan akan materi kewirausahaan. Keberhasilan pendidikan hanya diukur dari prestasi yang dicapai oleh siswa.

Idealnya pendidikan kewirausahaan yang diberikan disekolah dapat merangsang minat siswa untuk berwirausaha, sesuai dengan tujuan pendidikan kewirausahaan itu sendiri. Seharusnya pendidikan kewirausahan di sekolah menghasilkan output yang memiliki mental dan minat berwirausaha, dan dapat mempraktekkan pengetahuan yang diperolehnya dari sekolah di kehidupan nyata. Sesuai dengan pendapat Zimmerman dan Cleary (2006) yang menyatakan bahwa pendidikan kewirausahaan yang diberikan di sekolah selain dapat mengembangkan kemampuan kognitif siswa juga dapat mengembangkan keyakinan siswa dalam memecahkan masalah di kehidupan sosialnya. Berdasarkan pengertian diatas mengarahkan peneliti untuk merumuskan hipotesis ketiga yaitu:

$\mathrm{H}_{3}$ Pendidikan Kewirausahaan di Sekolah berpengaruh terhadap intensi berwirausaha siswa

\section{METODE PENELITIAN}

Penelitian ini merupakan penelitian explanatory research dengan pendekatan mix-method dilakukan dengan pendekatan kuantitatif yang kemudian dilengkapi dengan pendekatan kualitatif. Pendekatan kuantitatif digunakan untuk menjawab besar pengaruh variabel bebas terhadap variabel terikat yaitu intensi berwirausaha siswa dengan analisis regresi, pendekatan kualitatif digunakan untuk memperkuat hasil yang diperoleh dengan pendekatan kuantitatif. Adapun kerangka dalam penelitian ini dapat digambarkan sebagai berikut. 


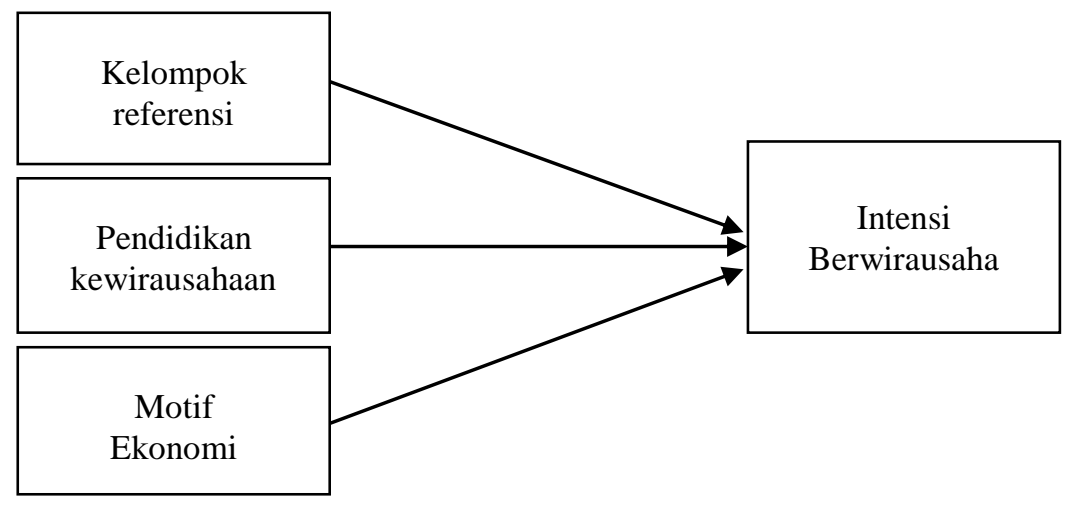

Gambar 1. Kerangka Penelitian

Populasi dalam penelitian ini adalah seluruh siswa SMK (SMEA) kelas XII Negeri dan Swasta yang berada di tingkat akhir sekolah menengah di Kota Malang yang yang telah dipersiapkan untuk memasuki dunia kerja, sekolah yang memiliki status "Disamakan" dan akreditasi "A", sampai dengan "B" dari jurusan Bidang Keahlian Bisnis dan Manajemen (Akuntansi, Pemasaran dan Administrasi Perkantoran). Penentuan sampel menggunakan teknik cluster sampling sehingga diperoleh jumlah sampel dalam penelitian ini berjumlah 261 siswa.

Pengumpulan data menggunakan angket yang terdiri dari dua bagian. Angket bagian A digunakan untuk memperoleh data yang berkaitan dengan demografi siswa seperti jenis kelamin, jurusan, pekerjaan orang tua dan jumlah uang saku serta jarak rumah tinggal dengan sekolah. Angket bagian B dibagi menjadi tiga bagian, bagian I digunakan untuk mengumpulkan data tentang kelompok referensi, bagian II pendidikan kewirausahaan di sekolah dan bagian III digunakan untuk memperoleh data tentang motif ekonomi siswa. Wawancara mendalam digunakan untuk melengkapi data yang diperoleh melalui angket, wawancara ditujukan kepada responden berdasarkan kelompok pekerjaan orang tua (PNS, Swasta, Wirausaha, Tani, TNI, Guru, Buruh, lain-lain). Wawancara dilakukan dengan sampel jenuh, yaitu sampai peneliti merasa data yang diperoleh cukup, maka wawancara dikatakan telah selesai.

\section{HASIL PENELITIAN DAN PEMBAHASAN}

Perbandingan siswa SMK dengan bidang keahlian bisnis dan manajemen berdasarkan data diketahui bahwa SMK bidang keahlian bisnis dan manajemen lebih diminati oleh siswa dengan jenis kelamin perempuan dibandingkan dengan siswa laki-laki, perbandingan antara siswa perempuan dan laki-laki adalah 84:1. Berdasarkan data dari angket $\mathrm{B}$ bagian I diketahui bahwa orang tua mendukung responden untuk memilih karir wirausaha, terbukti dengan 60,15 persen responden mengakui bahwa mereka mendapatkan dukungan orang tua untuk menjadi wirausaha jika telah lulus sekolah. 
Tabel 1 Rekapitulasi analisis regresi untuk pengaruh variabel $X_{1}, X_{2}$ dan $X_{3}$ terhadap Y

\begin{tabular}{|c|c|c|c|c|c|}
\hline \multirow[t]{2}{*}{ Variabel } & \multirow{2}{*}{$\begin{array}{l}\text { Koefisien } \\
\text { regresi } \\
\text { (B) }\end{array}$} & \multirow[t]{2}{*}{ t hitung } & \multirow[t]{2}{*}{ Sig } & \multicolumn{2}{|c|}{ Korelasi } \\
\hline & & & & Parsial & $\begin{array}{c}\text { Koefisen } \\
\text { determinasi } \\
\text { parsial } \mathbf{r}^{2}\end{array}$ \\
\hline $\begin{array}{l}\text { Kelompok } \\
\text { Referensi }\left(\mathrm{X}_{1}\right)\end{array}$ & 0,266 & 3,683 & 0,000 & 0,224 & 0,050 \\
\hline $\begin{array}{l}\text { Motif } \\
\text { ekonomi }\left(\mathrm{X}_{2}\right)\end{array}$ & 0,531 & 7,804 & 0,000 & 0,438 & 0,192 \\
\hline $\begin{array}{ll}\text { Pendidikan } \\
\text { kewirausahaan } \\
\text { di } \quad \text { sekolah } \\
\left(\mathrm{X}_{3}\right) & \\
\end{array}$ & 0,317 & 3,929 & 0,000 & 0,238 & 0,057 \\
\hline \multicolumn{6}{|c|}{ Intensi berwirausaha $(\mathrm{Y})$} \\
\hline $\begin{array}{l}\mathrm{R} \text { square } \\
\mathrm{R}^{2} \text { disesuaikan } \\
\text { Multiple } \mathrm{R} \\
\text { Konstanta } \\
\mathrm{N}\end{array}$ & $\begin{array}{l}=0,3 \\
=0,3 \\
=0,6 \\
=-3, \\
=261\end{array}$ & & $\begin{array}{l}\text { F hitung } \\
\text { Signifikansi } \\
\alpha\end{array}$ & \multicolumn{2}{|r|}{$\begin{array}{l}=54,104 \\
=0,000 \\
=0,05\end{array}$} \\
\hline
\end{tabular}

(Sumber: Diolah Peneliti, 2014)

Dari hasil pengolahan diperoleh nilai Multiple $\mathrm{R}$ adalah 0,622 , hal ini menunjukkan bahwa ada hubungan yang kuat antara ketiga variabel bebas yaitu antara kelompok referensi, motif ekonomi dan pendidikan kewirausahaan terhadap variabel terikatnya yaitu intensi berwirausaha siswa SMK di Kota Malang. Sumbangan pengaruh variabel independen terhadap variabel dependen sebesar 38 persen, sedangkan sisanya dijelaskan oleh variabel lain yang tidak dimasukkan ke dalam model penelitian ini. Kelompok referensi kelompok sebaya mendukung responden untuk memilih karir wirausaha. Responden yang menjawab mendapat dukungan dari teman-teman sebaya untuk berwirausaha ada 48,66 persen, 43,68 persen merasa sangat didukung dan 7,66 persen lainnya merasa cukup.

Pengaruh langsung kelompok referensi terhadap intensi berwirausaha siswa adalah 0,053 . Hasil ini berarti bahwa hipotesis $1\left(\mathrm{H}_{1}\right)$ penelitian diterima, yang berarti bahwa kelompok referensi siswa yaitu keluarga dan teman sebaya berpegaruh secara positif dan signifikan terhadap intensi berwirausaha siswa SMK di Kota Malang. Dari Tabel 1 dapat dilihat bahwa angka probabilitas 0,000 ( $p<$ $0,05)$ sehingga hipotesis kerja pertama $\left(\mathrm{H}_{1}\right)$ diterima, artinya secara parsial ada pengaruh yang signifikan dari variabel kelompok referensi terhadap intensi berwirausaha siswa pada taraf siginifikansi 95 persen.

Bagheri dan Pihie (2010) menyatakan bahwa anak yang berasal dari keluarga wirausaha dan ikut terlibat di dalam menjalankan usaha keluarga meningkatkan keyakinan dan kepercayaan diri pada anak untuk menjadi wirausaha. Apabila siswa mendapatkan kesempatan untuk mengelola usaha dalam keluarga, maka tanpa disadari bahwa siswa telah mengambil pengetahuan dalam mengelola usaha. Bagi anak yang berasal dari keluarga wirausaha memiliki kesempatan untuk menjalankan usaha sejak usia dini dan ikut terlibat dalam usaha keluarga, siswa akan merasa yakin dan mampu mengatasi masalah dan yakin 
untuk menjalankan usaha sendiri di masa yang akan datang. Keluarga juga dapat memberikan pengaruh lewat kekuatan informasi dan kekuatan referensi yang dimiliki kepada siswa dalam mempertimbangkan pemilihan suatu karir yang akan ditekuninya.

Hasil penelitian ini mendukung hasil penelitian yang dikemukakan oleh Chen dan Lai (2010) dalam penelitiannya di Taiwan menyatakan bahwa keinginan anak untuk berwirausaha di masa yang akan datang dapat dikuatkan dengan pengalaman yang dimiliki keluarganya dalam berwirausaha. Kesuksesan dan kegagalan yang dialami oleh keluarganya dalam menjalankan usaha dapat menguatkan keinginan anak untuk mengikuti jejak orang tuanya dan menjadi seorang wirausaha. Latar belakang ekonomi keluarga merupakan penghambat pemilihan karir yang diminati oleh siswa. Minat siswa akan suatu pekerjaan berawal dari ketertarikan dan merupakan sumber yang mendorong siswa untuk melakukan suatu kegiatan. Siswa yang berasal dari keluarga kurang mampu cenderung untuk langsung masuk dunia kerja atau menjadi pencari kerja. Melakukan pekerjaan apapun yang diperolehnya setelah lulus sekolah untuk membantu ekonomi keluarga walaupun pekerjaan tersebut tidak sesuai dengan minat dan potensi yang dimilikinya. Walaupun latar belakang pekerjaan orang tua bukan wirausaha, namun tidak menutup kemungkinan bagi anak untuk memperoleh pendidikan kewirausahaan dalam keluarga. Pendidikan kewirausahaan yang diperoleh oleh anak dalam keluarga selain keteladan orang tua dalam berwirausaha juga dapat melalui komunikasi orang tua mengenai kewirausahaan. Semakin sering komunikasi dalam keluarga yang diberikan oleh orang tua tentang kewirausahaan, maka semakin bertambah pula pengetahuan yang diterima oleh anak.

Meskipun berasal dari keluarga yang berwirausaha, namun jika transfer ilmu atau informasi akan kewirausahaan antara orang tua dan anak kurang, maka minat anak untuk berwirausaha juga rendah. Transfer ilmu kewirausahaan antara orang tua dan anak dapat berupa pengalaman orang tua dalam memenuhi kebutuhan sehari-hari, intensitas komunikasi dengan anak, semakin sering komunikasi akan kewirausahaan dilakukan maka semakin bertambah pula pengetahuan anak akan kewirausahaan. Pendidikan kewirausahaan dalam keluarga tidak seperti pendidikan disekolah yang mempunyai tujuan yang tercantum dalam kurikulum. Pendidikan kewirausahaan dalam keluarga tidak memiliki batas waktu dan tolak ukur penilain, dan dapat berlangsung kapan saja. Pendidikan kewirausahaan dalam keluarga dapat berupa komunikasi untuk menambah pengetahuan anak akan kewirausahaan, bentuk keteladanan orang tua dalam pemenuhan kebutuhan sehari-hari. Cara orang tua dalam meraih suatu keberhasilan dalam pemenuhan kebutuhan keluarga merupakan modal yang baik untuk melatih minat.

Kelompok referensi teman sebaya berdasarkan hasil penelitian dapat diketahui memiliki pengaruh terhadap intensi berwirausaha siswa, hasil penelitian ini mendukung hasil temuan Humbert dan Drew (2010) bahwa salah satu faktor yang memepengaruhi keinginan seseorang untuk berwirausaha adalah faktor teman. Teman sebaya adalah tempat dimana siswa dapat bersosialisasi, aturan dan norma yang berlaku dalam kelompok dapat mempengaruhi siswa untuk mengambil keputusan. Pemilihan karir wirausaha juga dipengaruhi oleh harapan harapan mahasiswa akan karir yang baik, pengembangan karir serta harapan akan 
pendapatan yang lebih baik. Kelompok referensi memiliki pengaruh terhadap pertimbangan, sudut pandang serta keinginan siswa untuk memilih suatu karir yang akan ditekuninya.

Dari Tabel 1 dapat dilihat bahwa angka probabilitas $0,000(p<0,05)$ sehingga hipotesis kerja kedua $\left(\mathrm{H}_{2}\right)$ diterima, artinya secara parsial ada pengaruh yang signifikan dari variabel motif ekonomi terhadap intensi berwirausaha siswa pada taraf siginifikansi 95 persen. Hasil penelitian ini mendukung hasil penelitian Humbert dan Drew (2010) dan Dow (2005) yaitu faktor motif untuk memenuhi kebutuhan, motif untuk memperoleh keuntungan, motif untuk memperoleh penghargaan, motif untuk memperoleh kekuasaan, dan motif sosial serta motif untuk memberikan yang lebih baik kepada keluarga menjadi alasan yang mendasar bagi siswa untuk memilih kewirausahaan sebagai pilihan karir mereka. Keadaan ekonomi keluarga yang saat ini sedang dirasakan oleh siswa dan keinginan untuk mendapatkan dan menghasilkan yang lebih baik menjadi alasan yang paling sering muncul sebagai alasan dalam berwirausaha.

Berdasarkan hasil wawancara mendalam yang dilakukan setelah memperoleh data kuantitatif, dengan pertanyaan "Siapakah pihak dalam keluarga Anda yang mendukung keinginan Anda untuk berwirausaha?" dapat diketahui bahwa kelompok referensi keluarga yaitu Ayah sebagai kepala keluarga menjadi pihak yang paling dominan dalam mendukung siswa untuk berwirausaha. Status pekerjaan orang tua tidak mempengaruhi intensi siswa dalam berwirausaha selama kepala keluarga mendukung dan mendorong siswa untuk berwirausaha, dapat disimpulkan bahwa kepala keluarga tidak memaksakan suatu karir kepada anakanaknya dan mendukung keinginan anak untuk memilih sendiri karir yang hendak ditekuninya.

Suatu motif adalah kebutuhan yang distimulasi dan dicari individu yang berorientasi pada tujuan untuk mencapai rasa puas. Harapan-harapan individu akan masa depan yang lebih baik akan menjadi motifnya untuk berperilaku mewujudkan harapan-harapan tersebut. Dorongan atau stimulasi yang muncul bagi setiap individu untuk melakukan aktifitas ekonomi guna memperoleh alat pemuas kebutuhan dalam penelitian ini disebut motif ekonomi. Dalam kajian ini, motif ekonomi di pahami sebagai alasan individu yang mendorong untuk memilih wirausaha sebagai pilihan karir.

Motif ekonomi memiliki pengaruh yang signifikan dibandingkan dengan variabel kelompok referensi dan pendidikan kewirausahaan di sekolah. Berdasarkan hasil wawancara mendalam kepada siswa dapat disimpulkan bahwa motif ekonomi memberikan kontribusi yang tinggi kepada siswa dalam memilih suatu karir. Motif untuk memiliki keadaaan ekonomi yang lebih baik dari keadaan sekarang, menjadi alasan yang paling sering muncul dalam hasil wawancara mendalam yang dilakukan oleh peneliti. Ketidakinginan untuk menjadi pegawai negeri muncul sebagai alasan bagi siswa untuk memilih wirausaha menjadi karir yang akan ditekuni. Siswa SMK berpandangan bahwa menjadi seorang pegawai negeri harus melalui tes, tes yang sangat kompetitif karena banyaknya peserta tes. Siswa SMK merasa tidak yakin untuk menjadi pegawai negeri dengan bermodalkan pendidikan SMK, dimana peserta lainnya mungkin memiliki pendidikan yang lebih tinggi. Siswa SMK merasa bekerja dibawah perintah orang lain kurang menyenangkan, sehingga mereka lebih cenderung untuk memilih wirausaha sebagai karir. 
Berdasarkan wawancara mendalam yang dilakukan peneliti dapat diketahui bahwa pemilihan wirausaha sebagai karir dikarenakan siswa tidak tertarik untuk bekerja dibawah perintah orang lain atau menjadi PNS (Pegawai Negeri Sipil). Pemilihan karir wirausaha dianggap sebagai upaya untuk meningkatkan status sosial ekonomi keluarga. Keinginan untuk bekerja sendiri tanpa diperintah oleh orang lain menjadi alasan utama siswa dalam memilih wirausaha menjadi karir. Keinginan untuk tidak menjadi pegawai negeri yang harus menjalani tes menjadi alasan utama siswa dalam berwirausaha. Hasil penelitian ini juga mendukung penelitian Aziz, et al (2013) yang menyatakan motif untuk memiliki status ekonomi dan memberikan yang lebih baik kepala keluarga adalah motif yang paling mempengaruhi seseorang dalam memilih wirausaha sebagai karir.

Pandangan positif ini memberikan mereka keyakinan bahwa berwirausaha merupakan pilihan yang lebih baik dari pada bekerja dibawah perintah orang lain. Siswa tidak berpandangan negatif tentang resiko yang harus dihadapi wirausaha dengan usaha baru, hal ini membuat siswa SMK antusias untuk memilih wirausaha sebagai karir. Namun sangat disayangkan sikap antusias ini tidak didukung dengan perencaan yang matang, terbukti melalui wawancara bahwa siswa tidak dapat memberikan detail langkah-langkah yang harus dipersiapkan dalam memulai kegiatan wirausaha. Motif ekonomi memberikan siswa tujuan yang hendak dicapai namun tidak diikuti dengan langkah-langkah untuk mencapai tujuan tersebut, dan motif ekonomi hanya mempengaruhi keinginan siswa untuk berwirausaha namun tidak untuk benar-benar membuka usaha (berwirausaha) atau dengan kata lain hanya sebatas ingin menjadi wirausaha bukan membuka usaha.

Dari Tabel 1 dapat dilihat bahwa angka probabilitas $0,000(p<0,05)$ sehingga hipotesis kerja ketiga $\left(\mathrm{H}_{3}\right)$ diterima, artinya secara parsial ada pengaruh yang signifikan dari variabel pendidikan kewirausahaan di sekolah terhadap intensi berwirausaha siswa pada taraf siginifikansi 95 persen. Pendidikan kewirausahaan yang diterima siswa disekolah dalam penelitian ini tidak dihubungkan dengan hasil belajar yang dicapai siswa dalam pembelajaran kewirausahaan, melainkan lebih kepada materi dan proses pembelajaran kewirausahaan itu sendiri. Tujuan pendidikan kewirausahaan di SMK adalah untuk mengembangkan potensi akademis dan kepribadian siswa, dan menguasai ilmu pengetahuan serta teknologi sesuai dengan kebutuhan dunia kerja.

Pengetahuan dan pengalaman siswa yang diperoleh dari sekolah baik melalui materi yang diberikan dan praktik kewirausahaan mempengaruhi penilaian berwirausaha siswa, karena siswa merasa bahwa materi kewirausahaan yang diterimanya dari sekolah itu bermanfaat dan dapat dipraktekkan di kehidupan nyata. Temuan penelitian ini mendukung penelitian Chen dan Lai (2010) bahwa pendidikan dan pengetahuan yang diterima siswa akan mempengaruhi minat dan pilihan siswa untuk memenuhi kebutuhannya sendiri di masa yang akan datang. Intensi berwirausaha dapat muncul ketika siswa merasa yakin bahwa pengetahuan yang diperolehnya dari sekolah dirasa bermanfaat dan menimbulkan kreatifitas siswa untuk berwirausaha.

Pendidikan kewirausahaan di SMK dilakukan dengan memberikan materi dalam kelas serta praktek lapangan. Praktek lapangan dapat berupa berbagai macam kegiatan sesuai ketentuan sekolah serta kurikulum yang diterapkan di sekolah. Kurikulum Sekolah Menengah Kejuruan (SMK) dikembangkan sebagai 
upaya untuk memenuhi kebutuhan pengembangan program sekolah yang berbasis pada tuntutan dan potensi daerah. Strategi ini merupakan upaya untuk meningkatkan peran SMK dalam rangka pengembangan wilayah melalui peningkatan kualitas sumber daya manusia profesional dan produktif sehingga program sekolah mampu menyatu kuat dengan masyarakatnya.

Tabel 2 Standar Kompetensi dan Kompetensi Dasar Mata Diklat Kewirausahaan SMK (SMEA)

\begin{tabular}{|c|c|}
\hline Standar Kompetensi & Kompetensi Dasar \\
\hline $\begin{array}{l}\text { 1. Mengaktualisasikan sikap } \\
\text { dan perilaku wirausaha } \\
\text { (Kode A) }\end{array}$ & $\begin{array}{ll}\text { 1.1 } & \begin{array}{l}\text { Mengidentifikasi sikap dan perilaku } \\
\text { wirausahawan }\end{array} \\
\text { 1.2 } & \begin{array}{l}\text { Menerapkan sikap dan perilaku kerja } \\
\text { prestatif (selalu ingin maju) }\end{array} \\
\text { 1.3 } & \text { Merumuskan solusi masalah } \\
\text { 1.4 } & \text { Membuat keputusan }\end{array}$ \\
\hline $\begin{array}{l}\text { 2. Merencanakan pengelolaan } \\
\text { usaha kecil } \\
\text { (Kode B) }\end{array}$ & $\begin{array}{l}\text { 2.1 Menganalisis peluang usaha } \\
\text { 2.2 } \begin{array}{l}\text { Menganalisis aspek-aspek pengelolaan } \\
\text { usaha berdasarkan aspek organisasi }\end{array} \\
\text { usaha dan aspek produksi } \\
\text { 2.3 } \begin{array}{l}\text { Menganalisis aspek-aspek pengelolaan } \\
\text { usaha berdasarkan aspek administrasi }\end{array} \\
\text { usaha } \\
\text { 2.4 Menganalisis aspek-aspek pengelolaan } \\
\text { usaha berdasarkan aspek pemasaran } \\
\text { 2.5 Menganalisis aspek-aspek pengelolaan } \\
\text { usaha berdasarkan aspek permodalan dan } \\
\text { pembayaran usaha } \\
\text { 2.6 Menyusun proposal usaha }\end{array}$ \\
\hline $\begin{array}{l}\text { 3. Mengelola usaha kecil } \\
\text { (Kode C) }\end{array}$ & $\begin{array}{l}\text { 3.1 Mempersiapkan pendirian usaha } \\
\text { 3.2 Menghitung rasio menjalankan usaha } \\
\text { 3.3 Menjalankan usaha kecil } \\
\text { 3.4 Mengevaluasi hasil usaha }\end{array}$ \\
\hline
\end{tabular}

(Sumber: Kurikulum SMK edisi 2006, Depdiknas Kota Malang)

Keterangan:

Kode $\mathrm{A} \quad=$ Mata diklat kewirausahaan yang diberikan pada kelas X

Kode $\mathrm{B} \quad$ = Mata diklat kewirausahaan yang diberikan pada kelas XI

Kode $\mathrm{C} \quad$ = Mata diklat kewirausahaan yang diberikan pada kelas XII

Berdasarkan tabel 2 dapat diketahui bahwa kurikulum SMK sudah memberikan konstribusi dalam memulai suatu usaha. Pendidikan kewirausahaan di sekolah berawal di kelas IX dampai pada kelas XII dimana siswa diberikan pembelajaran tentang memulai suatu usaha sampai dengan mengevaluasi kegiatan usaha. Namun disayangkan hal ini tidak banyak membantu siswa dalam mempersiapkan suatu usaha. Pembelajaran pada Kode $\mathrm{C}$ yang diberikan kepada siswa kelas XII yang menjadi responden dalam penelitian ini belum tertanam dengan baik kepada siswa, sehingga dalam hasil wawancara siswa masih belum dapat menentukan langkah-langkah yang harus diambil untuk berwirusaha meskipun materi tentang mengelola usaha kecil sudah diberikan di sekolah. Hal ini dibuktikan berdasarkan hasil wawancara mendalam yang dilakukan siswa 
belum mampu mengidentifikasikan langkah-langkah yang harus dilakukan untuk membuka suatu usaha. Siswa lebih banyak menjawab untuk mengumpulkan modal sebagai langkah pertama yang harus diambil ketika akan memulai usaha. Sangat disayangkan sampai dengan wawancara berakhir siswa tidak mampu menjelaskan dengan detail tentang langkah-langkah yang akan ditempuh olehnya untuk mewujudkan keinginannya berwirausaha.

Standar kompetensi yang diberikan kepada kelas XII SMK (SMEA) adalah mengelola usaha kecil, dengan kompetensi dasar yaitu mempersiapkan pendirian usaha, menghitung rasio menjalankan usaha, menjalankan usaha dan mengevaluasi usaha. Untuk penyampaian materi tersebut diperlukan praktik agar siswa dapat mengalami sendiri kegiatan mengelola usaha kecil. Dari hasil penelitian pelaksanaan praktik dalam pembelajaran kewirausahaan telah dilakukan oleh hampir seluruh SMK (SMEA) di Kota Malang. Dikarenakan pendidikan kewirausahaan dalam penelitian ini tidak dihubungkan dengan hasil belajar maupun prestasi siswa disekolah sehingga tidak mengukur pengetahuan siswa akan materi kewirausahaan, namun lebih kepada pandangan dan anggapan siswa tentang pendidikan kewirausahaan di sekolah yang dapat menimbulkan intensi siswa memilih wirausaha sebagai karir.

Hasil wawancara menunjukkan bahwa pendidikan kewirausahaan di sekolah tentang mengelola usaha kecil yang diberikan di kelas XII masih belum tertanam dengan baik kepada siswa. Meskipun pembelajaran kewirausahaan disekolah tidak hanya dilakukan dengan memberikan materi namun juga praktek. Dalam kegiatan praktek mengelola usaha siswa bekerja dalam kelompok dan memberlakukan praktik usahanya sebagai perusahaan, siswa menggunakan imajinasinya, kreatifitasnya dan fleksibilitasnya dalam mengelola usaha yang lebih membutuhkan bimbingan dan pengarahan daripada pengaturan. Siswa masih kesulitan dalam mengidentifikasi langkah-langkah menjadi wirausaha. Jawaban wawancara ini mendukung jawaban pada wawancara sebelumnya yang membuktikan bahwa siswa memiliki pandangan yang positif tentang wirusaha dan antusias untuk memilih wirausaha sebagai pilihan karir mereka.

Pandangan positif siswa terhadap wirausaha sebagai karir namun tidak diimbangi dengan pengetahuan mendalam tentang kegiatan dan resiko yang dilakukan dalam berwirausaha. Berdasarkan hasil wawancara dapat diketahui bahwa siswa memiliki pemikiran yang positif tentang wirusaha, terbukti dengan tidak ada satupun siswa yang menyatakan resiko negatif (rugi) dalam berwirausaha. Hal ini membuktikan bahwa siswa antusias dan berpandangan positif untuk memulai karir berwirausaha.

Bidang usaha yang menurut pandangan siswa menarik untuk ditekuni dalam berwirausaha adalah bidang fashion dan makanan. Bidang fashion menjadi pilihan dikarenakan bidang fashion memiliki tren yang selalu berubah-ubah serta banyaknya peminat fashion yang memberikan peluang bagi wirausaha baru. Berdasarkan pengalaman siswa sendiri bahwa dunia fashion yang selalu berubahubah serta selera masyarakat yang berubah dengan mengikuti suatu tren yang ada memberikan banyak peluang bagi siswa untuk berkreatifitas dalam usaha fahion. Bidang makanan dipilih oleh siswa dikarenakan bidang makanan merupakan bidang yang mudah untuk dilaksanakan dengan segera setelah mereka lulus sekolah nantinya, dikarenakan makanan dalam hal ini makanan ringan adalah bidang yang menarik dan mudah dilakukan serta tidak memerlukan banyak modal 
usaha. Berdasarkan hasil wawancara ini menunjukkan bahwa kecenderungan siswa memilih wirausaha sebagai karir tidak dipengaruhi oleh pilihan jurusan yang dipilihnya sekarang (jurusan bisnis dan manajemen). Siswa melihat secara positif kepada peluang yang diberikan oleh bidang fashion dan makanan sebagai suatu bidang yang menguntungkan untuk ditekuni.

\section{SIMPULAN}

Kelompok referensi siswa yaitu keluarga dan teman sebaya memiliki pengaruh yang positif dan signifikan terhadap intensi berwirausaha siswa. Pihak yang mendukung siswa dalam kelompok referensi keluarga adalah Ayah, sebagai kepala keluarga yang memberikan informasi dan dukungan kepada siswa yang pada akhirnya dapat meyakinkan siswa untuk memilih wirausaha sebagai pilihan karir.

Motif ekonomi untuk memenuhi kebutuhan, motif untuk memperoleh keuntungan, motif untuk memperoleh penghargaan, motif untuk memperoleh kekuasaan, dan motif sosial serta motif untuk memberikan yang lebih baik kepada keluarga menjadi alasan yang mendasar bagi siswa untuk memilih kewirausahaan sebagai pilihan karir mereka. Keadaan ekonomi keluarga yang saat ini sedang dirasakan oleh siswa dan keinginan untuk mendapatkan dan menghasilkan yang lebih baik menjadi asalah yang paling sering muncul sebagai alasan dalam berwirausaha. Keinginan untuk bekerja sendiri tanpa diperintah oleh orang lain menjadi alasan utama siswa dalam memilih wirausaha menjadi karir. Keinginan untuk tidak menjadi pegawai negeri yang harus menjalani tes menjadi alasan utama siswa dalam berwirausaha.

Pendidikan kewirausahaan yang diterima siswa disekolah dalam penelitian ini tidak dihubungkan dengan hasil belajar yang dicapai siswa dalam pembelajaran kewirausahaan, melainkan lebih kepada materi dan proses pembelajaran kewirausahaan itu sendiri. Pengetahuan dan pengalaman siswa yang diperoleh dari sekolah baik melalui materi yang diberikan dan praktik kewirausahaan mempengaruhi penilaian berwirausaha siswa, karena siswa merasa bahwa materi kewirausahaan yang diterimanya dari sekolah itu bermanfaat dan dapat dipraktekkan di kehidupan nyata . Intensi berwirausaha dapat muncul ketika siswa merasa yakin bahwa pengetahuan yang diperolehnya dari sekolah dirasa bermanfaat dan menimbulkan kreatifitas ssiwa untuk berwirausaha. Tujuan pendidikan kewirausahaan di SMK adalah untuk mengembangkan potensi akademis dan kepribadian siswa, dan menguasai ilmu pengetahuan serta teknologi sesuai dengan kebutuhan dunia kerja.

Siswa memiliki pemikiran yang positif tentang wirusaha, terbukti dengan tidak ada satupun siswa yang menyatakan resiko negatif (rugi) dalam berwirausaha. Hal ini membuktikan bahwa siswa antusias dan berpandangan positif untuk memulai karir berwirausaha. dunia fashion yang selalu berubah-ubah serta selera masyarakat yang berubah dengan mengikuti suatu tren yang ada memberikan banyak peluang bagi siswa untuk berkreatifitas dalam usaha fahion. Bidang makanan menjadi pilihan dominan kedua setelah fashion dikarenakan makanan dalam hal ini makanan ringan adalah bidang yang menarik dan mudah dilakukan serta tidak memerlukan banyak modal usaha. 
Pendidikan kewirausahaan di sekolah dapat dikatakan masih belum tertanam dengan baik kepada siswa, sehingga siswa masih kesulitan dalam mengidentifikasikan langkah-langkah yang harus dilakukan dalam memulai suatu usaha sedangkan materi mengelola usaha kecil sudah diberikan. Pembelajaran kewirausahaan disekolah perlu ditingkatkan, usaha memperbaiki proses pembelajaran agar siswa benar-benar memahami kewirausahaan dan bagaimana memulai suatu usaha sehingga siswa tidak lagi kesulitan untuk menentukan langkah dalam berwirausaha.

\section{DAFTAR RUJUKAN}

Acs, Z.J. \& J.E. Amorós, 2008. Entrepreneurship and Competitiveness Dynamics in Latin America. Small Business Economics Vol. 31 No. 3 pp. 305-322.

Acs, Z.J., S. Desai., L.F. Klapper, 2008. What Does "Entrepreneurship" Data Really Show?. Small Business Economics Vol. 31 No.3 pp. 265-281.

Aziz, N., Friedman, B., Bopieva, A., Keles, I. 2013. Entrepreneurial Motives and Perceived Problems: An Empirical Study of Entrepreneurs in Kyrgyzstan. Internasional Journal of Business Vol. 18 No. 2 pp. 163-176

Badan Pusat Statistik, 2015. Tenaga Kerja. http:// malangkota.bps.go.id /LinkTabelStatis/view/id/264 (Online) diakses pada 25 Agustus 2015.

Bandura, Albert, 1991. Social Cognitive Theory of Self-Regulation. Organizational Behavior and Human Decision Processes Vol. 50 pp. 248287

Bagheri, A. \& Pihie, Z., 2010. Role of Family in Entrepreneurial Leadership Development of University Students. World Applied Sciences Journal Vol. 11 No. 4 pp. $434-442$

Bristol, T. \& Mangleburg, T., 2005. Not Telling The Whole Story: Teen Deception in Purchasing. J. Acad. Mark. Sci. Vol. 33 No. 1 pp. 79-95.

Birdthistle, N., Hynes, B., Fleming, P. 2007. Enterprise Education Programmes in Secondary Schools in Ireland A Multi-stakeholder Perspective. Education + Training Vol. 49 No. 2 pp. 265-276.

Carraher, S. M., Buchanan, J. K., Puia, G. 2010. Entrepreneurial need for achievement in China, Latvia, and the USA. Baltic Journal of Management Vol. 5 No. 3 pp. 378-396.

Chen, Y. \& Lai, M. 2010. Factors Influencing The Entrepreneurial Attitude of Taiwanese Tertiary-Level Business Students. Social Behavior and Personality Vol. 38 No. 1pp. 1-12

Dow, Sheila C., 2005. Axioms and Babylonian Thought: A Reply. Journal of post Keynesian Economic Vol 27. No 3 pp. 385-391

Fatoki, O. 2010. Graduate entrepreneurial intention in South Africa: Motivations and obstacles. International Journal of Business and Management Vol. 5 No. 9 pp. 87-98.

Grilo, I., and J.M. Irigoyen. 2006. Entrepreneurship in the EU: To Wish and Not to Be. Small Business Economics Vol. 26 No. 4 pp. 305-318.

Humbert, A. L. \& Drew, E., 2010. Gender, Entrepreneurship, And Motivational Factors in An Irish Context. International Journal of Gender and Entrepreneurship Vol. 2 No. 2 pp. 173-196. 
Jogiyanto, H., 2007. Sistem Informasi Keprilakuan. Jogyakarta: Andi.

Kobia, M., \& Sikalieh, D., 2010. Towards A Search For The Meaning of Entrepreneurship. Journal of European Industrial Training, Vol. 34 No. 2 pp.110-127.

Kotter, J. 1997. The New Rules How to succeed in Today's Post-Corporate World. New York: The free press A division Simon \& Schuster Inc.

Kompas. 2009. Banyak Lulusan SMK Acuhkan Ijazah. http://edukasi.kompas.com/read/2009/05/17/0331275/Banyak.Lulusan.SMK .Acuhkan.Ijazah (Online) diakses pada 25 Agustus 2015.

Rahma, Ulifa. 2010. Bimbingan Karier Siswa. Malang: UIN-Maliki Press.

Rani, Pinki, 2014. Factors Influencing Consumer Behaviour. Int.J.Curr.Res.Aca.Rev Vol 2. No 9 pp. 52-61

Singh, S., Simpson, R., Okafor, C. 2011. Motivation to become an entrepreneur: A study of Nigerian Women's' decisions. African Journal of Economic and Management Studies Vol. 2 No. 2 pp. 202-219.

Soemanto, W., 1999. Sekuncup Ide Operasional Pendidikan Wiraswasta. Jakarta: Bumi Aksara

Suryana, 2003. Kewirausahaan. Jakarta: Salemba Empat

Thurik, R. and S. Wennekers. 2004. Entrepreneurship, Small Business, and Economic Growth. Journal of Small Business and Enterprise Development, Vol. 11 No. 1, pp. 140-149.

Yalcin, S. \& Kapu, H. 2008. Entrepreneurial Dimensions in Transitional Economies: A Review of Relevant Literature and The Case of Kyrgyzstan. Journal of Developmental Entrepreneurship Vol. 13 No. 2 pp. 185-204.

Zimerman, B. \& Cleary, T. 2006. Adolescents' Development of Personal Agency The Role of Self-efficacy Beliefs and Self-Regulatory Skill. Self-Efficacy Beliefs of Adolescents pp. 45-69 